\title{
Clinical, Hematological, Blood Gasometric and Electrolytic Changes in Dogs Receiving Whole Blood Transfusions
}

\author{
Mariana Elisa Pereira', Darlan Henrique Canei', Yolanda Paim Arruda Trevisan', \\ Carolina Zorzo ${ }^{2}$, Adriane Jorge Mendonça ${ }^{3}$, Jaqueline Konrad ${ }^{4}$, \\ Arleana do Bom Parto Ferreira de Almeida ${ }^{3}$ \&Valéria Régia Franco Sousa ${ }^{3}$
}

\begin{abstract}
Background: Blood transfusion is a tool capable of saving lives. Patients undergoing blood transfusion usually present several alterations in the acid-base and electrolyte balance, aggravating the condition of critically ill patients. Some studies have demonstrated haematological alterations in certain species that received whole blood transfusions, however, few studies have evaluated acid base and electrolyte changes in dogs undergoing whole blood haemotherapy. The aim of this study was to analyze clinical, hematological, blood gas and electrolyte changes in anemic dogs after whole blood transfusion. Materials, Methods \& Results: Twenty nine dogs transfused due to anemia were enrolled in the study. Donors blood was collected in a transfusion bag containing citrate phosphate adenine dextrose and stored up to $24 \mathrm{~h}$. Blood collections and evaluations were made before and $24 \mathrm{~h}$ after the transfusion. Data distribution normality was tested by the Shapiro Wilk Test. The means of the variables were compared by paired t-test. It was observed an increase in diastolic blood pressure and a reduction in heart rate $(P<0.05)$. There was a not significant increase in systolic blood pressure, temperature, and a reduction in respiratory rate per minute. Erythrocyte, haemoglobin and haematocrit averages were significantly increased after blood transfusion $(P<0.05)$. It was observed a reduction in the mean values of $\mathrm{pH}(P<0.05)$, potassium $(P>0.05)$ and ionized calcium $(P>0.05)$ and an increase in the mean partial pressure of carbon dioxide $\left(\mathrm{pCO}_{2}\right)(P<0.001)$, bicarbonate $(P>0.05)$ and sodium $(P<0.05)$. The probable cause of anemia was monocytic ehrlichiosis $(14 / 29)$, visceral leishmaniasis (1/29), babesiosis (1/29), co-infection of Ehrlichia canis and Leishmania infantum (2/29), co-infection of E. canis and Babesia vogeli (1/29). It was not possible to determine the etiology of the anemia in ten dogs.

Discussion: Heart rate significantly reduced after transfusion, probably because of the increase in hematocrit, hemoglobin and erythrocyte values. It may be justified by the displacement of extravascular fluid to the intravascular space. Mean values of systolic blood pressure were slightly elevated before transfusion and remained elevated afterwards, while diastolic and mean arterial pressure increased significantly after transfusion. These changes may be due to the morbid condition and may be influenced by many other factors. Haematocrit, haemoglobin and erythrocyte values increased significantly after transfusion, according to what was observed in other studies. The significant reduction in $\mathrm{pH}$ and increase in $\mathrm{pCO}_{2}$ reflects the compensatory mechanism for metabolic acidosis to increase ventilation, leading to $\mathrm{pCO}_{2}$ reduction and changes in $\mathrm{pH}$. The reduction in $\mathrm{pH}$ due to the contact of the collected blood with conservative solutions is one of the main changes thar occurs during blood storage. It was described significantly lower $\mathrm{pH}$ in dogs' whole blood samples stored for more than $24 \mathrm{~h}$ in vacutainer plastic containing CPDA-1. We may assume there was no intense $\mathrm{pH}$ reduction in the present study because the bags were stored for up to $24 \mathrm{~h}$. Although not statistically significant, the increase of $\mathrm{pO}_{2}$ mean reflects the improvement of tissue oxygen perfusion. It was observed a significant increase in sodium ions. The mean sodium ion concentration before transfusion was very close to the maximum reference value. Hyperkalaemia was not observed, nor was there significant reduction of potassium ions after transfusion. Several studies report hyperkalaemia and transfusion-associated cardiac arrests in humans, associated with infusion of large volumes of blood. Whole blood transfusion increased erythrogram values and did not negatively affect the electrolyte or acid-base status, representing a safe and useful tool in the intensive care of small animals.
\end{abstract}

Keywords: hemotherapy, acidosis, hypernatremia, canine.

DOI: $10.22456 / 1679-9216.113009$

Accepted: 18 June 2021

Published: 14 July 2021

${ }^{1}$ Programa de Pós-Graduação em Ciências Veterinárias (PPGVET); ${ }^{2}$ Programa de Residência Uniprofissional em Medicina Veterinária (PRUMV); ${ }_{3}^{3}$ Faculdade de Medicina Veterinária \& ${ }^{4}$ Setor de Clínica Médica de Pequenos Animais (CMPA) do Hospital Veterinário (HOVET), Universidade Federal de Mato Grosso (UFMT), Cuiabá, MT, Brazil. CORRESPONDENCE: V.R.F. SOUSA [valeriaregia27@ gmail.com]. Av. Fernando Corrêa da Costa nº 2367. CEP 78060-900 Cuiabá, MT, Brazil. 


\section{INTRODUCTION}

Blood transfusion is a life-saving emergency procedure that can lead to several adverse reactions $[21,41,46]$. For this reason, non-infectious transfusionassociated complications have been closely analyzed for many years [44]. Some studies have investigated the hematological changes in certain species transfused with whole blood [14,23,27,38], but few studies have evaluated acid-base and electrolyte changes in dogs undergoing hemotherapy [23,28].

Whole blood units include red blood cells, white blood cells, platelets and plasma. More recently, it is possible to separate and use each part according to the animal's needs, decreasing the risk of adverse reactions. In some cases, the patient is given a whole blood transfusion because there is no availability of the separated blood components. It is admissible when the patient is able to manage the blood volume expansion [45].

Electrolyte abnormalities and acid-base status disturbances must be thoroughly observed and rapidly treated because these may lead to fatal consequences. Recognizing acid-base status and serum electrolytes disturbances on an early stage is of high importance for clinical management, because it signals the disease gravity and the risk of death [7]. Accurate evaluation, monitoring and treatment are essential for an appropriate approach to the patient [4]. Thus, this study aimed to evaluate clinical, hematological, blood gasometric and electrolytic parameters in severely anaemic dogs before and after whole blood transfusion.

\section{MATERIALS AND METHODS}

\section{Dogs (blood recipients)}

A prospective study was conducted from June 2018 to June 2019, with 29 dogs greater than 1 year, of different breeds and with any underlying disease that received a whole blood transfusion.

The owners had been previously informed about the study objective, the blood collections and the clinical and laboratorial analysis performed before and after the transfusion. The animals were included in the study after the signature of the informed consent form.

The dogs were treated according to the indicated protocol for each case. None of the animals underwent anaesthesia or surgery or had been previously transfused. Blood transfusion was warranted due to severe anemia defined as an intense reduction in haematocrit (Ht) (below 15\%) and haemoglobin values $(\mathrm{Hb})$ (less than $5 \mathrm{~g} / \mathrm{dL}$ ) [34]. In cases that signs of acute adverse reactions (urticarial, emesis, diarrhea and facial oedema) were noted during blood transfusions, the animals were excluded from the study.

\section{Donors blood sampling}

Healthy donors were previously selected [5]. Their blood samples were collected for hemogram [42] and crossmatch. The crossmatch was adapted from a described protocol [29] to verify agglutination on an optical microscope in the major and minor tests, and control of the donor and the recipient. Blood transfusions were performed even in cases where agglutination was observed, due to the scarce blood availability.

Blood was collected from the jugular vein of the donors dogs in a transfusion bag containing citrate phosphate adenine dextrose (CPDA-1) ${ }^{1}$ as an anticoagulant. The bags were stored for no more than $24 \mathrm{~h}$ in an INDREL ${ }^{\circledR 2}$ blood bank refrigerator at 2 to $4^{\circ} \mathrm{C}$. The amount of whole blood to be transfused was calculated [5] , approximately $20 \mathrm{~mL} / \mathrm{kg}$, with an intended haematocrit of $25 \%$.

\section{Clinical and laboratory evaluation}

All evaluations and blood collections on the recipient dogs were performed immediately before and $24 \mathrm{~h}$ after the transfusion. Clinical examination was performed to determine attitude, heart and respiratory rate, temperature, blood pressure, colour of oral and ocular mucous membranes and clinical signs suggestive of transfusion reactions (e.g. vomiting, diarrhea, face oedema). Blood was infused on the cephalic vein after the limb antisepsis and the transfusion period did not exceed $4 \mathrm{~h}$.

Systolic and diastolic blood pressures were measured using pet-MAP ${ }^{\circledR 3}$, an oscillometric device, according to the manufacturer's instructions. The proper cuff was placed around the forelimb below the elbow, and 5 consecutive measurements were recorded in order to calculate the mean systolic and diastolic arterial blood pressure [1].

Recipient's biological samples were collected after antisepsis and included approximately $1.5 \mathrm{~mL}$ of whole blood in a tube containing ethylenediamine tetraacetic acid (EDTA) for complete blood count by a Poche 100 Haematology Analyzer ${ }^{4}$, with subsequent blood smear verification [42]. Approximately $3 \mathrm{~mL}$ of 
blood were collected from jugular vein in a clot activator tube to measure total calcium and protein after centrifugation at $2851 \mathrm{~g}$ for $5 \mathrm{~min}$, using commercial kits on the Wiener ${ }^{\circledR}$ Automated Biochemical Analyzer ${ }^{5}$ [30]. The measurement of ionized calcium (iCa) was calculated [12] and based on previously described values [23].

For blood gasometry, approximately $1 \mathrm{~mL}$ of venous blood was collected in heparin-coated syringes via jugular venipuncture [15] for analysis within $3 \mathrm{~min}$ of collection on the Cobas b1214 blood gas analyzer. Immediately following the collection for blood gasometric analysis, air bubbles were expelled from the syringe to avoid contact with oxygen. The values obtained were analyzed according to the literature $[9,15]$.

\section{Statistical analysis}

Results were tabulated in spreadsheets and analyzed using the Past statistical program [20]. The normality of data distribution of the measured variables was tested by the Shapiro Wilk Test. The means of the variables at both time points were compared using a paired $t$-test. A $P$ value below 0.05 was considered statistically significant.

\section{RESULTS}

Of the 29 dogs evaluated in the study, 14 were females and 15 were males, from 14 different breeds. Mixed-breed dogs predominated $(\mathrm{n}=13)$, followed by: Akita $(n=1)$, Australian Cattle Dog $(n=1)$, Boxer ( $n$ $=1)$, Chow Chow $(n=1)$, Golden Retriever $(n=1)$, Labrador Retriever $(n=1)$, Maltese $(n=1)$, German Shepherd ( $n=1)$, Pinscher $(n=1)$, American Pitbull ( $n$ $=4)$, Poodle $(n=1)$, Rottweiler $(n=1)$, and Shih Tzu $(n=1)$. The average age was 6.17 years with a median age of 6 years. Body mass ranged from $2.5 \mathrm{~kg}$ to 49 $\mathrm{kg}$, with a mean of $16.91 \mathrm{~kg}$ and a median of $17.1 \mathrm{~kg}$.
The means of diastolic, mean, and systolic blood pressure $(\mathrm{mmHg})$ values, heart and respiratory rate per minute and temperature observed before and $24 \mathrm{~h}$ after the transfusion are described in Table 1. There was an increase in diastolic blood pressure and a reduction in heart rate with statistical significance. Although not significant, there was an increase in systolic blood pressure, temperature, and a reduction in respiratory rate per minute.

The values obtained on the erythrogram after transfusion indicated a significant increase in erythrocyte, haemoglobin, and haematocrit averages. Post-transfusion venous blood gas measures showed a reduction in the mean values of $\mathrm{pH}(P<0.05)$, potassium $\left(\mathrm{K}^{+}\right)[P>0.05]$ and ionized calcium (iCa) $[P$ $>0.05]$ and an increase in the mean partial pressure of carbon dioxide $\left(\mathrm{pCO}_{2}\right)[P<0.001]$, bicarbonate $\left(\mathrm{HCO}_{3}\right)[P>0.05]$ and sodium $\left(\mathrm{Na}^{+}\right)[P<0.05]$ (Table 2 ). Three animals were not included in the analysis of sodium due to the absence of values obtained before or after the transfusion.

Of the 29 dogs, 15 (51.7\%) did not show agglutination in the compatibility test, while 9 agglutinated on the major test (31\%), 3 on the minor test (10.3\%), and 2 on both $(6.9 \%)$. Twenty-one dogs $(72.4 \%)$ were treated with Ringer's lactate and 8 were given $(27.59 \%)$ $0.9 \%$ sodium chloride solution after transfusion, but none received sodium bicarbonate or electrolyte replacement within the first $24 \mathrm{~h}$.

Previous diagnostic of monocytic ehrlichiosis (14), visceral leishmaniasis (1), babesiosis (1), coinfection of Ehrlichia canis and Leishmania infantum (2), co-infection of E. canis and Babesia vogeli (1) were probably the anemia cause in the dogs. It was not possible to determine the etiology of the anemia in 10 dogs.

Table 1. Heart and Respiratory rate, temperature, mean diastolic, mean and systolic blood pressure values, heart rate, respiratory rate and temperature before and $24 \mathrm{~h}$ after blood transfusion.

\begin{tabular}{|c|c|c|c|}
\hline Parameter & $\begin{array}{l}\text { Before transfusion } \\
\qquad \mathrm{M}^{\ddagger} \pm \mathrm{sd}^{\S}\end{array}$ & $\begin{array}{l}\text { After transfusion } \\
\qquad M^{\ddagger} \pm \mathrm{sd}^{\S}\end{array}$ & $\begin{array}{c}\text { Paired } t \text {-test } \\
P\end{array}$ \\
\hline Heart Rate (BPM) & $138.6 \pm 5.5$ & $106.1 \pm 4.9$ & $<0.05^{*}$ \\
\hline Respiratory Rate (RPM) & $29.4 \pm 2.95$ & $28.6 \pm 2.4$ & $>0.05$ \\
\hline Temperature & $37.7 \pm 0.2$ & $37.8 \pm 0.1$ & $>0.05$ \\
\hline M. Diastolic (mmHg) & $84.4 \pm 5.3$ & $94 \pm 4.4$ & $<0.05 *$ \\
\hline M. Systolic (mmHg) & $106.48 \pm 4.78$ & $117.86 \pm 5.62$ & $<0.05 *$ \\
\hline Systolic (mmHg) & $151.7 \pm 5.8$ & $163.3 \pm 7.4$ & $>0.05$ \\
\hline
\end{tabular}


M.E. Pereira, D.H. Canei, Y.P.A. Trevisan, et al. 2021. Clinical, Hematological, Blood Gasometric and Electrolytic Changes in Dogs

Table 2. Mean haemogasometric values and standard deviation of dogs before and $24 \mathrm{~h}$ after whole blood transfusion.

\begin{tabular}{|c|c|c|c|c|c|}
\hline Parameter & $\mathrm{N}^{\dagger}$ & References Values & $\begin{array}{c}\text { Before transfusion } \\
\qquad \mathrm{M}^{\ddagger} \pm \mathrm{sd}^{\S}\end{array}$ & $\begin{array}{l}\text { After transfusion test } \\
\qquad M^{\ddagger} \pm \mathrm{sd}^{\S}\end{array}$ & $\begin{array}{c}\text { Paired } t \text {-test } \\
P\end{array}$ \\
\hline Erythrocytes $\left(\mathrm{x} 10^{6} / \mu \mathrm{L}\right)$ & 29 & $5.5-8.5$ & $1.54 \pm 0.41$ & $2.92 \pm 0.5$ & $<0.001^{*}$ \\
\hline $\mathrm{Hb}(\mathrm{g} / \mathrm{dL})$ & 29 & $12-18$ & $3.58 \pm 0.83$ & $6.7 \pm 1.01$ & $<0.001 *$ \\
\hline $\mathrm{Ht}(\%)$ & 29 & $37-55$ & $11.58 \pm 2.35$ & $21.59 \pm 3.47$ & $<0.001 *$ \\
\hline $\mathrm{pH}$ & 29 & $7.35-7.44$ & $7.37 \pm 0.07$ & $7.34 \pm 0.08$ & $<0.05^{*}$ \\
\hline $\mathrm{pO}_{2}(\mathrm{mmHg})$ & 29 & $47.9-56.3$ & $35.34 \pm 7.55$ & $37.39 \pm 9.50$ & $>0.05$ \\
\hline $\mathrm{pCO} 2(\mathrm{mmHg})$ & 29 & $33.6-41.2$ & $25.94 \pm 6.32$ & $29.96 \pm 5.12$ & $<0.001 *$ \\
\hline $\left.\mathrm{HCO}_{3}^{-(} \mathrm{mmol} / \mathrm{L}\right)$ & 29 & $20.8-24.2$ & $15.22 \pm 4.53$ & $16.54 \pm 3.83$ & $>0.05$ \\
\hline $\mathrm{Na}^{+}(\mathrm{mmol} / \mathrm{L})$ & 26 & $140-155$ & $153.82 \pm 7.61$ & $157.41 \pm 8.32$ & $<0.05^{*}$ \\
\hline $\mathrm{iCa}(\mathrm{mmol} / \mathrm{L})$ & 29 & $1.2-1.4$ & $4 \pm 0.9$ & $3.8 \pm 1.19$ & $>0.05$ \\
\hline $\mathrm{K}^{+}(\mathrm{mmol} / \mathrm{L})$ & 29 & $3.5--5.8$ & $3.63 \pm 0.84$ & $3.39 \pm 0.61$ & $>0.05$ \\
\hline
\end{tabular}

$\dagger \mathrm{N}=$ number of dogs; $† \mathrm{M}=$ mean; $\S \mathrm{sd}=$ standard deviation; * statistical significance.

\section{DISCUSSION}

In this study, in which 29 dogs received whole blood transfusion, the mean values of heart rate, respiratory rate and temperature of the dogs before and after the transfusion were within the normal range [18]. However, heart rate showed a significant reduction 24 $\mathrm{h}$ after the transfusion, probably due to the increase in hematocrit, hemoglobin, and erythrocyte values. The decrease in heart rate can be justified by the displacement of extravascular fluid to the intravascular space, due to the infusion of blood [32].

Reduced respiratory rate, another compensatory mechanism when there is anemia, was observed during whole blood [32]. However, in our study there were no significant changes in respiratory rate. There was no significant increase in the mean rectal temperature $(P<0.05)$, which remained within the reference range $\left(37.5^{\circ} \mathrm{C}-39.2^{\circ} \mathrm{C}\right)$ for dogs [18].

The values $(\mathrm{mm} \mathrm{Hg})$ of systolic pressure in healthy dogs ranged from 131 to 150 , while the diastolic pressure from 71 to 91 and the mean pressure from 97 to 110 . Mean values of systolic blood pressure were slightly elevated before transfusion and remained elevated afterwards, with no significant difference between times, while diastolic and mean arterial pressure increased significantly after transfusion. These changes may result from the morbid condition itself and may be influenced by age, race, sex [6] even in healthy dogs as described in the consensus on systemic hypertension in dogs and cats [1].

The patient's temperament, whose stress and anxiety increase during care and hospitalization, result- ing from the white coat syndrome, causes significant interference in the measurement of pressure [2]. The stress response leads to the activation of neurohumoral systems, such as the hypothalamus-pituitary-suprarenal axis, with the release of cortisol and the sympatheticadrenal-medullary system, which causes the release of catecholamines, adrenaline and noradrenaline, mainly [35].

As expected, the haematocrit, haemoglobin and erythrocyte values increased significantly $(P<$ 0.001 ) after whole blood transfusion in anemic dogs [39]. Similar increases in haemoglobin and haematocrit concentrations have been reported after red blood cell transfusion in euvolemic, anaemic dogs [26]. A study with anaemic cats and induced hypotension detected that blood transfusion increased arterial and venous blood pressure in consequence of volemia restoration [10].

It was observed a significant reduction in $\mathrm{pH}(P$ $<0.05)$ and increase in $\mathrm{pCO}_{2}(P<0.001)$. The compensatory mechanism for metabolic acidosis is to increase ventilation, leading to $\mathrm{pCO}_{2}$ reduction and changes in $\mathrm{pH}$ [8]. Although it has been described that bicarbonate ion concentration assumes the same behaviour as $\mathrm{pCO}_{2}$, no significant increase in bicarbonate ions $(P>$ 0.05) was observed.

The reduction of $\mathrm{pH}$ is one of the main changes that occurs when collected blood contacts the conservative solutions. As the cells continue their metabolism, the $\mathrm{pH}$ is reduced at a rate proportional to the storage time [36]. A study described significantly lower $\mathrm{pH}$ in dogs' whole blood samples stored for more than $24 \mathrm{~h}$ 
in vacutainer plastic containing CPDA-1 [33], while another study demonstrated that goats transfused with whole blood bags stored for 15 days presented with lower $\mathrm{pH}$ values than animals transfused with fresh whole blood [17] . From this information, we can assume there was no intense $\mathrm{pH}$ reduction in the present study because the bags were stored for no more than $24 \mathrm{~h}$.

Measurement of venous $\mathrm{pO}_{2}$ is useful in cases that metabolic variables such as tissue perfusion and oxygen demand are to be evaluated, as its concentration is defined by oxygen supply and consumption by tissues [11]. Although it was described that venous blood is ineffective in measuring $\mathrm{pO}_{2}$ as it presents discrepant values in relation to arterials [40], measuring venous $\mathrm{pO}_{2}$ is useful in cases where it is desired to evaluate metabolic variables, such as tissue perfusion and oxygen demand, as its concentration is defined by the supply and consumption of oxygen by the tissues [16]. Thus, though not statistically significant $(P>$ $0.05)$, the increase of the mean $\mathrm{pO}_{2}$ after transfusion reflects the improvement of tissue oxygen perfusion.

There was no significant reduction in mean calcium ion values after whole blood transfusion $(P>0.05)$, although hypocalcaemia is described as a consequence of the binding of calcium with citrate used as an anticoagulant in the bloodstream [13,23].

There was a significant increase in sodium ions $(P<0.05)$ beyond the reference range after transfusion. Hypernatremia frequently occurs in critically ill patients and it was associated with the use of mannitol, renal failure, mechanical ventilation and an increased mortality rate [3]. A higher mortality rate was detected in hypernatremic animals, even with mild increases [43]. Anorexia, lethargy, emesis, muscle weakness, ataxia, seizures and death have all been associated with hypernatremia in dogs and cats [19]. In this study, none of the patients exhibited clinical signs associated with post-transfusion hypernatremia. Importantly, the mean sodium ion concentration before transfusion was very close to the maximum reference value.

As the solution of choice for fluid therapy in most dogs (72.4\%) was lactated Ringer's, the increase in sodium cannot be justified by the interference of infused fluid [24]. Of the $8 \mathrm{dogs}$ that received $0.9 \%$ sodium chloride solution after transfusion, only 4 had hypernatremia after $24 \mathrm{~h}$. To clarify this question, a $t$-test simulation was performed, disregarding the patients that were administered $0.9 \%$ sodium chloride solution, and yet, a significant increase in sodium ions was detected $(P<0.05)$.

Several studies report hyperkalaemia and transfusion-associated cardiac arrests in humans, usually related to the infusion of large volumes of blood $[25,31,37]$. Such events may be justified by the increase in potassium concentration during blood storage secondary to the normal erythrocyte lysis that occurs within the first $2 \mathrm{~h}$ after transfusion or during the bag storage, causing the release of intracellular potassium ions [44]. Dogs do not get hyperkalemic due to haemolysis because most breeds do not have significant potassium ion concentrations in their erythrocytes, with the exception of Akita dogs [23] . There was only one Akita dog in the present study, which did not present with hyperkalaemia in any of the collections. In fact, hyperkalaemia was not observed in the present study, nor was there significant reduction of potassium ions $(P>0.05)$ after transfusion. Severe hypokalaemia is associated with severe changes such as arrhythmias, paralysis, rhabdomyolysis and interference with diaphragm contraction capacity [22].

The limitations of our study were no availability of compatible blood to be administered in some cases and the impossibility to diagnose the cause of anemia in all dogs. Additionally, it was not possible to associate the variety of clinical presentations of the infections that lead to anemia with the analyzed parameters.

\section{CONCLUSION}

Blood transfusion increased erythrogram values and did not negatively affect the electrolyte or acid-base status, representing a safe and useful tool in the intensive care of small animals. However, it is recommended that dogs undergoing blood transfusion be monitored for changes in calcium and sodium ion concentrations as well as changes in acid-base balance.

\section{MANUFACTURERS}

${ }^{1}$ JP Pharmaceutical Industry. Ribeirão Preto, SP, Brazil.

${ }^{2}$ Indrel Scientific. Londrina, PR, Brazil.

${ }^{3}$ Ramsey Medical Inc. Tampa, FL, USA.

${ }^{4}$ Roche Diagnostics. São Paulo, SP, Brazil.

${ }^{5}$ Wiener Lab Group. Rosário, Argentina.

Acknowledgements. The authors thank the Coordination of Higher Education Personnel Improvement for the postgraduate scholarship. 
Ethical approval. This study was approved by the Ethics Committee on the Use of Animals (CEUA) of the Federal University of Mato Grosso (UFMT) under protocol number no. 23108.938920/2018-37.
Declaration of interest. The authors declare that they have no conflict of interest. The authors alone are responsible for the content and writing of the paper.

\section{REFERENCES}

1 Acierno M.J., Brown S., Coleman A.E., Jepson R.E., Papich M., Stepien R.L. \& Syme H.M. 2018. ACVIM consensus statement: Guidelines for the identification, evaluation, and management of systemic hypertension in dogs and cats. Journal of Veterinary Internal Medicine. 32(6): 1803-1822.

2 Acierno M.J. \& M.A. Labato. 2004. Hypertension in Dogs and Cats. Compendium on Continuing Education for Practicing Veterinarian. 26(5): 336-345.

3 Aiyagari V., Deibert E. \& Diringer M.N. 2006. Hypernatremia in the neurologic intensive care unit: how high is too high? Journal of Critical Care. 21(2): 163-172.

4 Artero C.T. 2017. A quick reference on Anion Gap and Strong Ion Gap. Veterinary Clinics of North America - Small Animal Practice. 47(2): 191-196.

5 Barreto E.P.L. 2009. Transfusão Sanguínea em Cães: Revisão de Literatura. 41f. Salvador, BA. Monografia (Especialização em Clínica Médica de Pequenos Animais) - Departamento de Pequenos Animais, Universidade Federal Rural do Semi-Árido.

6 Brown S., Atkins C., Bagley R., Carr A., Cowgill L., Davidson M., Egner B., Elliott J., Henik R., Labato M., Littman M., Polzin D., Ross L., Snyder P. \& Stepien R. 2007. ACVIM consensus statement: Guidelines for the Identification, Evaluation, and Management of Systemic Hypertension in Dogs and Cats. Journal of Veterinary Internal Medicine. 21(3): 542-558.

7 Carausu E.M., Trandafir V., Ghibu L., Stamatin O. \& Checherita L.E. 2017. Study of electrolyte serum disturbances and acid-base status in patients with oral-maxillofacial and dental sepsis. Revista de Chimie. 68(7): 1552-1556.

8 Carella C.C. \& Morais H.A. 2017. Compensation for Acid-Base Disorders. Veterinary Clinics of North America Small Animal Practice. 47(2): 313-323.

9 Carlson G.P. \& Bruss M. 2008. Fluid, Electrolyte, and Acid-Base Balance. In: Kaneko J.J., Harvey J.W. \& Bruss M.L. (Eds). Clinical Biochemistry of Domestic Animals. 6th edn. Amsterdam: Academic Press, pp.529-560.

10 Cartana C.B. 2010. Transfusão de sangue obtido de doadores anestesiados com cetamina e xilazina ou isoflurano em gatos hipovolêmicos.40f. Santa Maria, RS. Dissertação (Mestrado em Medicina Veterinária) - Programa de PósGraduação em Medicina Veterinária, Universidade Federal de Santa Maria.

11 Clutton R.E. 1998. Blood gas analysis. In: Fuentes V.L \& Swift S. (Eds). BSAVA Small Animal Cardiorespiratory Medicine and Surgery. Cambridge: British Small Animal Veterinary Association, pp.101-103.

12 Conceicao S.C., Weightman D., Smith P.A, Luno J., Ward M.K. \& Keer D.N.S. 1978. Serum ionised calcium concentration. British Medical Journal. 1: 1103-1105.

13 Corazza M.L. \& Hranchook A.M. 2000. Massive Blood Transfusion Therapy. American Association of Nurse Anesthetists Journal. 68(4): 311-314.

14 Costa J., Viana J.A., Ribeiro Filho J.D., Favarato E.S., Mata L.C. \& Argôlo Neto N. 2008. Parâmetros bioquímicos e hemogasométricos do sangue total canino armazenado em bolsas plásticas contendo CPDA-1 e CPD/SAG-M. Ciência Rural. 38(2): 378-383.

15 DiBartola S. 2012. Introduction to Acid-Base Disorders. In: DiBartola S.P. (Ed). Fluid, Electrolyte Acid-Base Disord. 4th edn. St. Louis: Elsevier, pp.231-252.

16 Dourado A. 2010. Estudos de variações de gasometria venosa e indicadores de perfusão em canídeos em síndrome de choque. 77f. Dissertação (Mestrado Integrado em Medicina Veterinária) - Universidade Técnica de Lisboa, Lisboa.

17 Fonseca N.B.S., Gameleira J.S., Cavalcante J.M., Oliveira F.L.C., Mori C.S., Sousa R.S., Minervino A.H.H. \& Barrêto Júnior R.A. 2018. Biochemical responses, blood gas, oxidative stress and lipid peroxidation of goats transfused with fresh or stored whole homologous blood. Pesquisa Veterinária Brasileira. 38(11): 2080-2087.

18 Futema F. 2002. Avaliação pré-anestésica, In: Fantoni D.T. \& Cortopassi S.R.G. (Eds). Anestesia em Cães e Gatos. São Paulo: Editora Roca, pp.59-63. 
19 Guillaumin J. \& DiBartola S.P. 2017. A Quick Reference on Hypernatremia. Veterinary Clinics of North America Small Animal Practice. 47(2): 209-212.

20 Hammer O., Harper D.A.T. \& Ryan P.D. 2001. Past: Paleontological Statistics Software Package for Education and Data Analysis. Palaentologia Electronica. 4(1): 1352-1357.

21 Hohenhaus A.E. 2000. Transfusion reactions. In: Feldman B.F., Zinkl J.G. \& Jain N.C. (Eds). Schalm's Veterinary Hematology. 5th edn. Baltimore: Lippincott Williams \& Wilkins, pp.864-868.

22 Jensen H.K., Brabrand M., Vinholt P.J., Hallas J. \& Lassen A.T. 2015. Hypokalemia in acute medical patients: Risk factors and prognosis. American Journal of Medicine. 128(1): 60-67.e1.

23 Jutkowitz L.A., Rozanski E.A., Moreau J.A. \& Rush J.E. 2002. Massive transfusion in dogs: 15 cases (1997-2001). Journal of the American Veterinary Medical Association. 220(11): 1664-1669.

24 Kamp-jensen M., Olesen K.L., Bach V., Schütten H.J. \& Engquist A. 1990. Changes in serum electrolyte and atrial natriuretic peptide concentrations, acid-base and haemodynamic status after rapid infusion of isotonic saline and ringer lactate solution in healthy volunteers. British Journal of Anaesthesia. 64(5): 606-610.

25 Kim D.W., Cheon K.R., Cho D., Lee K.S., Cho H.J. \& Jeong I.S. 2015. Transfusion associated hyperkalemia and cardiac arrest in an infant after extracorporeal membrane oxygenation. Korean Journal of Critical Care Medicine. 30(2): 132-134.

26 Kisielewicz C. \& Self I.A. 2014. Canine and feline blood transfusions: Controversies and recent advances in administration practices. Veterinary Anaesthesia and Analgesia. 41(3): 233-242.

27 Klaser D.A., Reine N.J. \& Hohenhaus A.E. 2005. Red blood cell transfusions in cats: 126 Cases (1999). Journal of the American Veterinary Medical Association. 226(6): 920-923.

28 Lamb J.L., Mankin K.M.T., Levine G.J. \& Thompson J. 2015. Electrolyte and acid/base changes in dogs undergoing autologous blood transfusion via a cell salvage device. Canadian Veterinary Journal. 56(9): 947-952.

29 Lanevschi A. \& Wardrop K.J. 2001. Principles of transfusion medicine in small animals. Canadian Veterinary Journal. 42(6): 447-454.

30 Langhorn R., Tarnow I., Willesen J.L., Kjelgaard-Hansen M., I.M. Skovgaard I.M. \& Koch J. 2014. Cardiac Troponin I and T as Prognostic Markers in Cats with Hypertrophic Cardiomyopathy. Journal of Veterinary Internal Medicine. 28(5): 1485-1491.

31 McEvoy M.D., Thies K.C., Einav S., Ruetzler K., Moitra V.K., Nunnally M.E., Banerjee A., Weinberg G., Gabrielli A., Maccioli G.A., Dobson G. \& O'Connor M.F. 2018. Cardiac arrest in the operating room: Part 2-special situations in the perioperative period. Anesthesia and Analgesia. 126(3): 889-903.

32 Morikawa M.K., Bochio M.M., Pincelli V.A., Freire R. \& Pereira P.P. 2010. Monitoração e avaliação clínica da eficácia da transfusão de sangue total e concentrado de hemácias em cães. Pesquisa Veterinaria Brasileira. 30(8): 665669.

33 Nnamdi O.H., Ijeoma U.R. \& Okaforx N.T. 2019. Stability of hematological parameters of canine blood samples stored with citrate phosphate dextrose adenine-1 anticoagulated plastic vacutainers. Veterinary World. 12(3): 449-453.

34 Ognean L., Chiurciu V., Ştefănuț C., Oana L., Morar I. \& Barabási I. 2015. Transfusion Triggers and Therapeutic Efficacy in a Group of Dogs That Underwent Whole Blood Therapy. Agriculture and Agricultural Science Procedia. 6: 363-369.

35 Pereira M.C. \& Ribeiro L. 2012. Estresse, Catecolaminas e Risco Cardiovascular. Arquivos de Medicina. 26(6): 245253.

36 Ribeiro Filho J.D., Almeira C.T., Gonçalves R.C., Kohayagawa A. \& Cury P.R. 1994. Alterações hemogasométricas de sangue bovino durante a conservação em frascos de vidro com ACD e bolsas plásticas com CPDA-1, por 35 dias. Veterinária e Zootecnia. 6: 77-84.

37 Smith H.M., Farrow S.J. \& Ackerman J.D. 2008. Cardiac arrests associated with hyperkalemia during red blood cell transfusion: a case series. Anesthesia and Analgesia. 106(4): 1062-1069.

38 Sousa R.S., Chaves D.F., Barrêto-Júnior R.A., Sousa I.K.F., Soares H.S., Barros I.O., Minervino A.H.H. \& Ortolani E.L. 2012. Clinical, haematological and biochemical responses of sheep undergoing autologous blood transfusion. BMC Veterinary Research. 8: 61. https://doi.org/10.1186/1746-6148-8-61.

39 Spinelli E. \& Bartlett R.H. 2016. Anemia and transfusion in crital care: physiology and management. Journal of Intensive Care Medicine. 31(5): 295-306. 
40 Sucupira M.C.A. \& Ortolani E.L. 2003. Uso de sangue arterial e venoso no exame do equilíbrio ácido-básico de novilhos normais ou com acidose metabólica. Ciência Rural. 33(5): 863-868.

41 Tiwari R.C. \& Sharma A.K. 2016. Importance of blood transfusion and associated risk factors. World Journal of Blood Transfusion and Associated Risk Factors. 5(5): 531-537.

42 Tvedten H. 2010. Laboratory and Clinical Diagnosis of Anemia. In: Weiss D.J \& Wardrop K.J. (Eds). Schalm's Veterinary Hematology. 6th edn. Ames: Blackwell Publishing, pp. 152-161.

43 Ueda Y., Hopper K. \& Epstein S.E. 2015. Incidence, severity and prognosis associated with hypernatremia in dogs and cats. Journal of Veterinary Internal Medicine. 29(3): 794-800.

44 Vraets A., Lin Y. \& Callum J.L. 2011. Transfusion-associated hyperkalemia. Transfusion Medicine Reviews. 25(3): 184-196.

45 Yagi K. 2016. Transfusion Medicine. In: Battaglia A.M \& Steele A.M. (Eds). Small Animal Emergency and Critical Care for Veterinary Technicians. 3rd edn. St. Louis: Elsevier, pp.78-105.

46 Yagi K. \& Spromberg L.A. 2018. Transfusion Medicine. In: C.L. Norkus (Ed). Veterinary Technician's Manual for Small Animal Emergency and Critical Care. 2nd edn. Oboken: John Wiley \& Sons, pp.505-529. 